\title{
Knowledge, Attitude, and Practice of Voluntary Blood Donation among Healthcare Workers at the University of Benin Teaching Hospital, Benin City, Nigeria
}

\author{
Benedict Nwogoh, ${ }^{1}$ Usimenahon Aigberadion, ${ }^{1}$ and Alexander Ikenna Nwannadi ${ }^{2}$ \\ ${ }^{1}$ Department of Haematology and Blood Transfusion, University of Benin Teaching Hospital, P.M.B 1111, Benin City 300283, Nigeria \\ ${ }^{2}$ Department of Haematology, Benue State University, Makurdi 102119, Nigeria
}

Correspondence should be addressed to Benedict Nwogoh; b.nwogoh@yahoo.com

Received 6 June 2013; Revised 31 July 2013; Accepted 21 August 2013

Academic Editor: Silvano Wendel

Copyright (C) 2013 Benedict Nwogoh et al. This is an open access article distributed under the Creative Commons Attribution License, which permits unrestricted use, distribution, and reproduction in any medium, provided the original work is properly cited.

\begin{abstract}
Introduction. Adequate and safe blood supply has remained a challenge in developing countries like ours. There is a high dependency on family replacement and remunerated blood donors in our environment which carries an attendant increased risk of transfusion transmissible infection. Objectives. The objectives of this study were to assess the knowledge, attitude, and practice of voluntary blood donation among healthcare workers (nonphysicians) and to identify and recruit potential voluntary blood donors. Methodology. This was a cross-sectional descriptive study carried out at the University of Benin Teaching Hospital, Benin City. A total of 163 staffs were recruited. Pretest questionnaires were used to assess their knowledge, attitude, and practice of voluntary blood donation. Statistical Analysis. The responses were collated and analyzed with the Statistical Package for Social Sciences (SPSS) 16. The association between blood donation practice and gender of respondents, category of staff, and level of education was tested using Chi-square and Fisher's tests where appropriate. $P<0.05$ were considered statistically significant. Results. The median age of the respondents was 32 years (18-56) with females accounting for $55.6 \%$ (90). A total of $74.8 \%$ (122) attained tertiary education, and $55.8 \%$ (91) of respondents were senior staffs. The majority has good knowledge and positive attitude towards donation; however, only $22.1 \%$ (36) have donated blood with $41.7 \%$ (15) of these being voluntary. Male workers were more likely to donate $(P<0.05)$. There is no significant association between blood donation and level of education. Conclusion. There is a strong disparity between the knowledge, attitude, and practice of voluntary donation amongst healthcare workers.
\end{abstract}

\section{Introduction}

In spite of extensive promising research, a true substitute for blood and blood components may not be available for many years [1]. Therefore, blood donation by humans will continue to be the major source for blood and blood components. There are no national data in Nigeria on blood donor demand and supply; however, available data suggest that over 7,000 units of blood are utilized annually at the University of Benin Teaching Hospital, most of which are provided by blood vendors $[2,3]$.

Donated blood can be lifesaving for individuals who have lost large volumes of blood from serious accidents, obstetric and gynecological hemorrhages, or surgery and stem cell transplant patients as well as for individuals who have symptomatic anemia from medical or hematologic conditions or cancers. Therefore, blood is an important concern to the society. The use of these life saving products may be complicated by infectious and immunological diseases some of which could be life threatening.

Blood banks are obligated to provide adequate and safe blood to the community. Generally, donors are classified into the following categories: voluntary, family replacement, remunerated or paid donors, and autologous donor. The safest donors are found among people who donate their blood voluntarily purely out of altruism and are self-aware of their unsuitability to serve as blood donors where there might be a slightest risk of causing health damage for blood recipients $[4,5]$. The risk of transfusion transmissible diseases is highest with the use of blood procured from remunerated donors 
$[2,3,6-9]$. A person in need for money is more likely to conceal his/her true state of health. Monetary remuneration, which is often offered as a donor motivating tool, might be highly appealing for people who live in desperate straits.

In developing countries like Nigeria, there is a dependency on family replacement and remunerated donors [3, 1012]. Voluntary blood donation accounts for less than $5 \%$ of blood procured in most of our blood banks [13]. The World Health Organization advocates that member states should establish national blood transfusion services that will operate on the basis of voluntary, nonremunerable blood donation [14]. Despite the establishment of National Blood Transfusion Service (NBTS) in Nigeria, very little progress has been made in the direction of providing sufficient blood for our teaming populace.

The attitude, beliefs, and level of knowledge associated with blood donation may affect the disposition of potential donors to blood donation. Health workers are expected to have a good knowledge of blood usage, to be aware of the increasing demand and scarcity of the products, and are thus expected to donate as well as encourage voluntary blood donation among the public.

\section{Study Objectives}

The objectives of this study were to assess the knowledge, attitude and, practice of voluntary blood donation among healthcare workers (nonphysicians), to identify and recruit potential voluntary blood donors and to determine the association between blood donation, gender, category of staff, and level of education of the staffs.

\section{Materials and Methods}

This was a cross-sectional descriptive study carried out at the University of Benin Teaching Hospital, Benin City. The centre operates a hospital-based blood banking system which is highly dependent on blood procurement from vendors who operate paid-donor outlets. Their supplies are augmented by supply from the National Blood Transfusion Service (NBTS), family replacement, and very few voluntary donors. The hospital has over 3,000 health workers (nonphysicians) in various departments.

The staffs are categorized as junior or senior staffs based on their academic qualifications and their job descriptions. Senior staffs are employed into positions requiring higher qualifications such as scientists, nurses, engineers, and accountants, while junior staffs are employed into positions which often do not require a university degree qualification such as office assistants, record clerks, and technicians.

Pretested questionnaires were used to assess their knowledge, attitude, and practice of voluntary blood donation. The questionnaire was modeled after that used in our earlier research work on voluntary donations by physicians [15].

A total of 250 health workers were recruited from the various departments by quota sampling to participate in the study.

Statistical Analysis. The responses were collated and analyzed with the Statistical Package for Social Sciences (SPSS) 16.
The association between blood donation practice and gender of respondents, category of staff, and level of education was tested using Chi-square and Fisher's tests where appropriate. $P<0.05$ were considered statistically significant.

\section{Results}

4.1. Demographic Parameters. A total of 163 health workers responded to the questionnaire giving a response rate of $65.2 \%$. The age range of the respondents was $18-56$ years (median age was 32 years). The male to female ratio is $1: 1.3$. Eighty-six (52.8\%) were married, while $75(46 \%)$ were singles. Most (74.8\% of respondents) attained tertiary education; ninety-one (55.8\%) were senior staffs, and 69 (42.3\%) were junior staffs. Nursing staffs were 30 (18.4\%), laboratory staffs 37 (22.7\%), pharmacy staffs 19 (11.7\%), and administrative workers 22 (13.5\%) among others. Details of their demographic parameters are represented in Table 1.

4.2. Knowledge of Blood Transfusion. A total of 151 (92.6\%) respondents expressed good knowledge of the common blood group types, and 153 (93.9\%) knew their own blood groups. The blood groups of respondent were A Rhesus (Rh) positive (25) (15.3\%), AB Rh positive (3) (1.8\%), B Rh positive (16) (9.8\%), O Rh negative (6) (3.7\%), and O Rh positive (74) (45.4\%). Thirty-five persons (21.5\%) did not respond, and 4 (2.5\%) responses were invalid.

Most respondents (157) (95.7\%) were aware of the risk of transmission of infection by transfusion. The risk of transmission of HIV, HBV, HCV, and Syphilis was affirmed by $91.4 \%$ (149), 69.9\% (114), 42.9\% (70), and 27.0\% (44), respectively.

Forty-four $(27 \%)$ stated that the minimum interval between donations is 6 months, 35 (21.5\%) said 3 months, and $13(8.0 \%)$ said a month, while $33(20.2 \%)$ said they have no knowledge of this.

The majority of the respondents had a good knowledge on who should and who should not donate. However, 6 $(3.7 \%)$ of the respondents said vulnerable group (sex workers, intravenous drug users) should donate. Twelve (7.4\%) and $10(6.1 \%)$ respondents said people should not donate for religious and cultural reasons, respectively.

Only $66(40.5 \%)$ knew the correct volume of blood collected in the process. Similarly, 59 (36.2\%) knew that the donation process lasts less than 20 minutes. Details of the respondents knowledge of blood donation are shown in Table 2.

4.3. Attitude towards Blood Donation. A hundred and thirtythree $(81.6 \%)$ respondents said blood donation was good. Voluntary donation was accepted as the best source of blood donors by $116(71.2 \%)$, replacement donors by $11(6.7 \%)$, remunerated by $3(1.8 \%)$, and self donation by $3(1.8 \%)$.

One hundred and twenty-five (71.2\%) said blood donation may have adverse consequences. Twenty (12.3\%) said a donor can contract infection, 99 (60.7\%) said the donor may experience temporary weakness, and 9 (5.5\%) said the donor may fall sick.

One hundred and forty-six (89.6\%) feels that patient relatives should be asked to donate, and 149 respondents have 
TABLE 1: Sociodemographic parameters of respondents.

\begin{tabular}{|c|c|c|}
\hline \multirow[t]{2}{*}{ (1) Age range (median age) } & \multicolumn{2}{|l|}{$18-56(32)$ yrs } \\
\hline & $N=163$ & Percentage $(\%)$ \\
\hline \multicolumn{3}{|l|}{ (2) Gender } \\
\hline Males & 69 & 42.3 \\
\hline Females & 90 & 55.2 \\
\hline No response & 4 & 2.5 \\
\hline \multicolumn{3}{|l|}{ (3) Marital status } \\
\hline Single & 75 & 46.0 \\
\hline Married & 86 & 52.8 \\
\hline Widow & 1 & 0.6 \\
\hline No response & 1 & 0.6 \\
\hline \multicolumn{3}{|l|}{ (4) Educational status } \\
\hline None & 1 & 0.6 \\
\hline Primary & 6 & 3.7 \\
\hline Secondary & 29 & 17.8 \\
\hline Tertiary & 122 & 74.8 \\
\hline No response & 5 & 3.1 \\
\hline \multicolumn{3}{|l|}{ (5) Category of staff } \\
\hline Junior & 69 & 42.3 \\
\hline Senior & 91 & 55.8 \\
\hline No response & 3 & 1.8 \\
\hline \multicolumn{3}{|l|}{ (6) Department } \\
\hline Nursing service & 30 & 18.4 \\
\hline Administration & 22 & 13.5 \\
\hline Pharmacy & 19 & 11.7 \\
\hline Laboratory (pathology) & 37 & 22.7 \\
\hline Records & 10 & 6.1 \\
\hline Accounts & 9 & 5.5 \\
\hline Dentistry & 6 & 3.7 \\
\hline Engineering & 6 & 3.7 \\
\hline Physiotherapy & 9 & 5.5 \\
\hline Radiology & 9 & 5.5 \\
\hline Others & 6 & 3.7 \\
\hline
\end{tabular}

asked relatives in the past to donate. Details of respondents' attitude to blood donation are shown in Table 3.

4.4. Practice of Blood Donation. Thirty-six (22.1\%) have donated in the past. Only 5 (13.9\%) were regular donors. Only $15(41.7 \%)$ are voluntary, and 19 (52.8\%) donated to a friend or relative in need of blood.

The reasons for nondonation by those who have not donated include nobody approached them for donation (32) (25.2\%), unfit to donate (21) (16.5\%), need to donate for a friend or relative in future (25) (19.7\%), fear of needle (8) $(6.3 \%)$, fear of knowing their viral status (4) (3.1\%), the donated blood may be sold (5) (3.9\%), nonremuneration (1) $(0.8 \%)$, and their religion prohibits blood donation (1) $(0.8 \%)$.

Sixty-seven $(41.1 \%)$ respondents accepted to be invited to donate blood, but only $32(19.6 \%)$ gave their contacts so that they can be reached.

There was a significant association between male gender and blood donation $(P=0.003)$ as shown in Table 4 . The
TABLE 2: Knowledge on blood donation.

\begin{tabular}{lc}
\hline $\begin{array}{l}\text { Do you know the common blood } \\
\text { groups? }\end{array}$ & \\
Yes & $151(92.6 \%)$ \\
No & $9(5.5 \%)$ \\
No response & $3(1.8 \%)$ \\
Do you know your blood group? & \\
Yes & $153(93.9 \%)$ \\
No & $7(4.3 \%)$ \\
No response & $3(1.8 \%)$ \\
Blood group of respondent? & \\
A Positive & $25(15.3 \%)$ \\
AB Positive & $3(1.8 \%)$ \\
B Positive & $16(9.8 \%)$ \\
O Negative & $6(3.7 \%)$ \\
O Positive & $74(45.4 \%)$ \\
Invalid & $4(2.5 \%)$ \\
No response & $35(21.5 \%)$ \\
Can a person be infected by receiving & \\
blood transfusion? & \\
Yes (correct) & $159(97.5 \%)$ \\
No (incorrect) & $2(1.2 \%)$ \\
No response & $2(1.2 \%)$
\end{tabular}

What diseases are transmissible by blood transfusion?

$\begin{array}{lc}\text { HIV } & 149(91.4 \%) \\ \text { HBV } & 114(69.9 \%) \\ \text { HCV } & 70(42.9 \%) \\ \text { Syphilis } & 44(27.0 \%) \\ \text { Malaria } & 7(4.3 \%) \\ \text { No response } & 5(3.1 \%) \\ \text { Weekly often can an individual donate? } & \\ \text { Monthly } & 3(1.8 \%) \\ 3 \text { Monthly } & 13(8.0 \%) \\ 6 \text { Monthly } & 35(21.5 \%) \\ \text { Annually } & 44(27 \%) \\ \text { Don't know } & 23(14.1 \%) \\ \text { Invalid } & 33(20.2 \%) \\ \text { No response } & 1(0.6 \%) \\ \end{array}$

Who should donate blood?

$\begin{array}{lc}\text { Men (correct) } & 132(81.0 \%) \\ \text { Women (correct) } & 112(81.0 \%) \\ \text { Young (<18 yrs) (incorrect) } & 12(7.4 \%) \\ \text { Old (>60 yrs) (incorrect) } & 4(2.5 \%) \\ \text { Vulnerable group (incorrect) } & 6(3.7 \%) \\ \text { Healthy (correct) } & 111(68.1 \%) \\ \text { Diseased (incorrect) } & 1(0.6 \%)\end{array}$


TABLe 2: Continued.

\begin{tabular}{lc}
\hline Who should not donate blood? & $7(4.3 \%)$ \\
Men (incorrect) & $13(8.0 \%)$ \\
Woman (incorrect) & $58(35.6 \%)$ \\
Young (<18 yrs) (correct) & $82(50.3 \%)$ \\
Old (>60 yrs) (correct) & $103(63.2 \%)$ \\
Vulnerable group (correct) & $4(2.5 \%)$ \\
Healthy (incorrect) & $107(65.6 \%)$ \\
Diseased (correct) & $10(6.1 \%)$ \\
Culture belief (incorrect) & $12(7.4 \%)$ \\
Religious belief & $7(4.3 \%)$ \\
No response & \\
What volume of blood is collected & \\
during each donation? & $66(40.5 \%)$ \\
$\leq 500$ mls (correct) & $37(22.7 \%)$ \\
$500-1000$ mls (incorrect) & $52(31.9 \%)$ \\
Don't know & $8(4.9 \%)$ \\
No response & \\
What is the duration of a donation & \\
process? & $59(36.2 \%)$ \\
$<20$ minutes (correct) & $43(26.4 \%)$ \\
$20-60$ minutes & $52(31.9 \%)$ \\
Don't know & $9(5.5 \%)$ \\
No response &
\end{tabular}

level of education and category of staff have no significant association with the practice of blood donation $(P=0.895$ and 0.334 , resp.) as shown in Tables 5 and 6 .

\section{Discussion}

The overdependence on family replacement and remunerated donors to meet the increasing demand for blood and blood products poses serious danger to potential recipient. Settings like ours which is still dependent on serological screening test for detection of transfusion transmissible infections in potential donors; who do not use pathogen nucleic acid detection technique; who do not practice pathogen inactivation; who do not leucodeplete nor irradiate blood products are more at risk. Hence, there is need to improve the recruitment and retention of voluntary-donor population to ensure a reasonably safe blood transfusion practice.

There are lots of publications assessing the knowledge, attitude, and practice of voluntary blood donation; however, very few studies have been published which assess the same on the healthcare workers in our environment and globally. This study has shown as expected that healthcare workers have a good knowledge of blood groups, possible transfusion transmissible infection, and the appropriate donor population but on the contrary exhibited a poor knowledge of the blood donation process.

The study also revealed a positive attitude of the workers towards blood donation, but there was a serious contradiction in the practice of voluntary blood donation. Though all study
TABle 3: Attitude and practice of blood donation.

\begin{tabular}{lc}
\hline & $N(\%)$ \\
\hline Section C: Attitude towards blood donation & \\
What do you think about blood donation? & $133(81.6)$ \\
Good & $8(4.9)$ \\
Bad & $20(12.3)$ \\
Neutral & $2(1.2)$ \\
No response & \\
What do you think is the best source of blood & \\
donors? & $116(71.2)$ \\
Voluntary donor & $11(6.7)$ \\
Replacement donor & $3(1.8)$ \\
Remunerated donor & $3(1.8)$ \\
Self donor & $8(4.9)$ \\
I don't know & $22(13.5)$ \\
No response &
\end{tabular}

Can something harmful happen to a blood donor during or after donation?

Yes

No

$30(18.4)$

I don't know

What can happen to a blood donor during or after donation?

Contract Infection

Temporary Weakness

Fall Sick

Should patient relatives be asked to donate?

Yes

No

I don't know

No response

$7(4.3)$

Section D: Practice of blood donation

Have you donated before?

Yes

No

How often do you donate?

$<1$ time a year

1-3 times a year

$>3$ times a year

No response

Why did you donate?

$\begin{array}{lc}\text { A friend or relative needed blood } & 19(52.8) \\ \text { Voluntary } & 15(41.7) \\ \text { Remuneration } & 1(2.7) \\ \text { To know my screening status } & 1(2.7)\end{array}$

Will you donate if called upon or reminded to do so?

Yes

No

No response

$45(27.6)$

Number of those who stated their contact 
TABLE 3: Continued.

\begin{tabular}{lc}
\hline & $N(\%)$ \\
\hline Reasons for non donation by nondonors & $32(25.2)$ \\
Not approached to donate & $21(16.5)$ \\
Unfit to donate & $25(19.7)$ \\
Need to donate for friends or relatives in future & $8(6.3)$ \\
Fear of needles & $4(3.1)$ \\
Fear of knowing my status & $1(0.8)$ \\
Religion forbids it & $5(3.9)$ \\
Donated blood may be sold & $1(0.8)$ \\
No remuneration & $39(30.7)$ \\
No response & \\
Do you encourage relatives to donate? & $149(91.4)$ \\
Yes & $7(4.3)$ \\
No & $7(4.3)$ \\
No response & \\
\hline
\end{tabular}

TABLE 4: The association between gender and blood donation.

\begin{tabular}{lccc}
\hline Gender & Donors $(\%)$ & Nondonors & Total \\
\hline Males & $23(14.5)$ & $46(28.9)$ & $69(43.4)$ \\
Females & $12(7.5)$ & $78(49.1)$ & $90(56.6)$ \\
\hline Total & $35(22.0)$ & $124(78.0)$ & $159(100)$ \\
\hline
\end{tabular}

$\chi^{2}=9.1, P=0.003$.

TABLE 5: The association between staff category and blood donation.

\begin{tabular}{lccc}
\hline $\begin{array}{l}\text { Category of } \\
\text { staff }\end{array}$ & Donors (\%) & Nondonors (\%) & Total (\%) \\
\hline Junior & $15(9.4)$ & $54(33.7)$ & $69(43.1)$ \\
Senior & $19(11.9)$ & $72(45.0)$ & $91(56.9)$ \\
\hline Total & $34(21.3)$ & $126(78.7)$ & $160(100.0)$ \\
\hline$\chi^{2}=0.017, P=0.895$. & &
\end{tabular}

TABLE 6: The association between staff level of education and blood donation.

\begin{tabular}{lccc}
\hline $\begin{array}{l}\text { Level of } \\
\text { education }\end{array}$ & Donors (\%) & Nondonors (\%) & Total (\%) \\
\hline Tertiary & $25(15.8)$ & $97(61.4)$ & $122(77.2)$ \\
Secondary & $7(4.4)$ & $22(13.9)$ & $29(18.3)$ \\
Primary & $3(1.9)$ & $3(1.9)$ & $6(3.8)$ \\
None & $0(0.0)$ & $1(0.6)$ & $1(0.6)$ \\
\hline Total & $35(22.1)$ & $123(77.9)$ & $158(100.0)$ \\
\hline
\end{tabular}

Fishers exact test, $P=0.334$.

participants are within the age range of potential donors, only $22.1 \%$ of them have donated blood in the past, out of which $52.8 \%$ were as family replacement and $41.7 \%$ voluntary. This is a far cry based on the knowledge and attitude displayed in this study and their experience of the increased demand for blood in the hospital. A total of 67 (41.1\%) of the participants accepted to be invited in the future for voluntary donation but only $32(19.6 \%)$ gave their contacts. This reflects the absence of commitment to their acceptance. Thus, there is a serious disparity in their knowledge, attitude, and practice.

In a similar study conducted on physicians in the same healthcare facility, a similar trend was observed, but higher proportion of donors and regular donors was reported in the physicians [15]. We recorded that $41.4 \%$ blood donation was by physicians, with $39.6 \%$ being regular donors and $53.4 \%$ of these were voluntary [15].

Study by Mullah et al. assessing the knowledge and perception of healthcare support staffs of a tertiary healthcare facility in Gujarat revealed a poor knowledge of donor eligibility among the staffs, $91 \%$ of them perceive blood donation as unsafe, and about $39 \%$ of them have donated blood [16].

In a similar study in Iran, Reza et al. assessed the knowledge of 122 healthcare workers and found that $51.6 \%$ (just above average) have acceptable knowledge on proper methods of blood and components transfusion [17]. Variation in knowledge of blood donation and transfusion processes may be attributable to the degree of enlightenment program available and the degree of involvement of staffs in blood and blood products management.

The major reason given by those who had never donated was that no one approached them to donate. This highlights the need for serious sensitization and education to all and sundry through the mass media to encourage the populace to approach the blood bank for a blood donation exercise.

This study found a significant association between blood donation and sex. Males in our society are more likely to donate blood than females. This is quite understandable since women within the donor age range usually may have one factor or another interfering with their chances of being suitable to donate. Factors such as their frequent menstrual cycles, pregnancy, and lactation may prevent them from donation. This is in affirmation of the WHO report that there are more male donors in Nigeria [18].

In conclusion, healthcare workers are reasonably informed and have positive perception towards blood donation; however, only few of them have donated and are positively disposed to donate blood. There is a need for active education program to encourage all, and sundry if adequate and safe blood will be guaranteed.

\section{References}

[1] K. C. Lowe and E. Ferguson, "Benefit and risk perceptions in transfusion medicine: blood and blood substitutes," Journal of Internal Medicine, vol. 253, no. 5, pp. 498-507, 2003.

[2] M. E. Enosolease, C. O. Imarengiaye, and O. A. Awodu, "Donor blood procurement and utilisation at the University of Benin Teaching Hospital, Benin City," African Journal of Reproductive Health, vol. 8, no. 2, pp. 59-63, 2004.

[3] B. Nwogoh, D. Ikponwen, and M. E. Isoa, "Donor blood procurement and the risk of transfusion transmissible viral infections in a tertiary health facility in South-South Nigeria," Nigerian Medical Journal, vol. 52, no. 4, pp. 227-229, 2011.

[4] A. M. Buyx, "Blood donation, payment, and non-cash incentives: classical questions drawing renewed interest," Transfusion Medicine and Hemotherapy, vol. 36, no. 5, pp. 329-339, 2009. 
[5] "Voluntary blood donation," http://www.who.int.

[6] T. Eastlund, "Monetary blood donation incentives and the risk of transfusion- transmitted infection," Transfusion, vol. 38, no. 9, pp. 874-882, 1998.

[7] C. L. Van der Poel, E. Seifried, and W. P. Schaasberg, "Paying for blood donations: still a risk?” Vox Sanguinis, vol. 83, no. 4, pp. 285-293, 2002.

[8] O. A. Ejele, O. Erhabor, and C. A. Nwauche, "The risk of transfusion-transmissible viral infections in the Niger-Delta area of Nigeria," Sahel Medical Journal, vol. 8, no. 1, pp. 16-19, 2005.

[9] S. A. Glynn, J. W. Smith, G. B. Schreiber et al., "Repeat wholeblood and plateletpheresis donors: unreported deferrable risks, reactive screening tests, and response to incentive programs," Transfusion, vol. 41, no. 6, pp. 736-743, 2001.

[10] Z. A. Jeremiah and B. B. Koate, "Anaemia, iron deficiency and iron deficiency anaemia among blood donors in Port Harcourt, Nigeria," Blood Transfusion, vol. 8, no. 2, pp. 113-117, 2010.

[11] A. O. Emeribe, A. O. Ejele, E. E. Attai, and E. A. Usanga, "Blood donation and patterns of use in southeastern Nigeria," Transfusion, vol. 33, no. 4, pp. 330-332, 1993.

[12] S. G. Ahmed, U. A. Ibrahim, and A. W. Hassan, "Adequacy and pattern of blood donations in north-eastern Nigeria: the implications for blood safety," Annals of Tropical Medicine and Parasitology, vol. 101, no. 8, pp. 725-731, 2007.

[13] "World Blood Donor Day: from ritual to implementation," Nigerian Compass Newspaper, 2010.

[14] “The Melbourne declaration on 100\% voluntary non-remunerated donation of blood and blood components," Composed at World Blood Donor Day. Melbourne, Australia, 2009.

[15] B. Nwogoh, U. S. Aigberadion, I. A. Nwannadi, and I. Aigbe, "Knowledge, attitude and practice of voluntary blood donation among physicians in a tertiary health facility of a developing country," International Journal of Blood Transfusion and Immunohematology, vol. 2, pp. 4-10, 2012.

[16] F. Mullah, D. Kumar, D. Antani, and M. Gupta, "Study of knowledge, perceptions and practices related to blood donation among the healthcare support staff of a tertiary care hospital in Gujarat, India," The Online Journal of Health and Allied Sciences, vol. 12, 2, no. 1, 2013.

[17] P. A. Reza, S. V. Aziz, M. A. Ali, M. H. Marjan, and T. M. Reza, "Evaluation of knowledge of healthcare workers in hospitals of Zabol city on proper methods of blood and components transfusion," Asian Journal of Transfusion Science, vol. 3, no. 2, pp. 78-81, 2009.

[18] "WHO report on Gender distribution of blood donors by country," Data Reported by WHO Global Database on Blood Safety, 2011. 


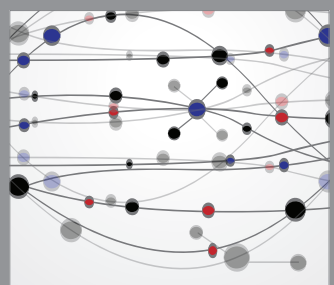

The Scientific World Journal
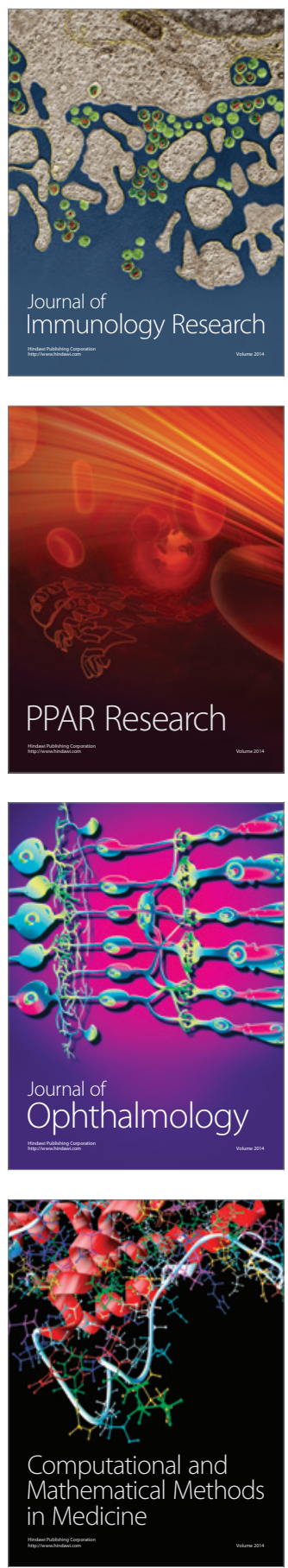

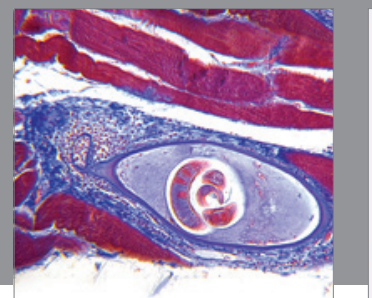

Gastroenterology

Research and Practice
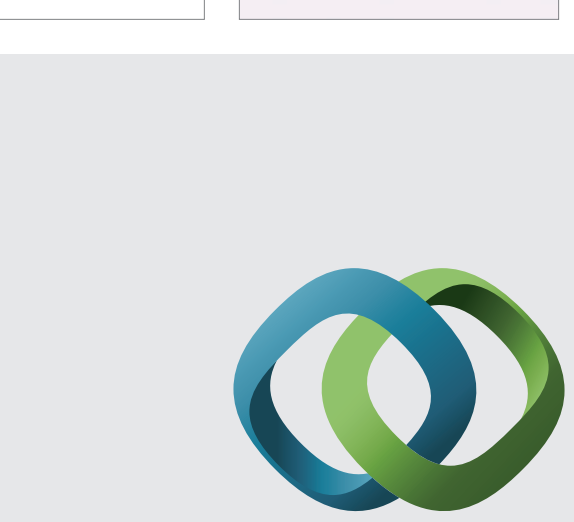

\section{Hindawi}

Submit your manuscripts at

http://www.hindawi.com
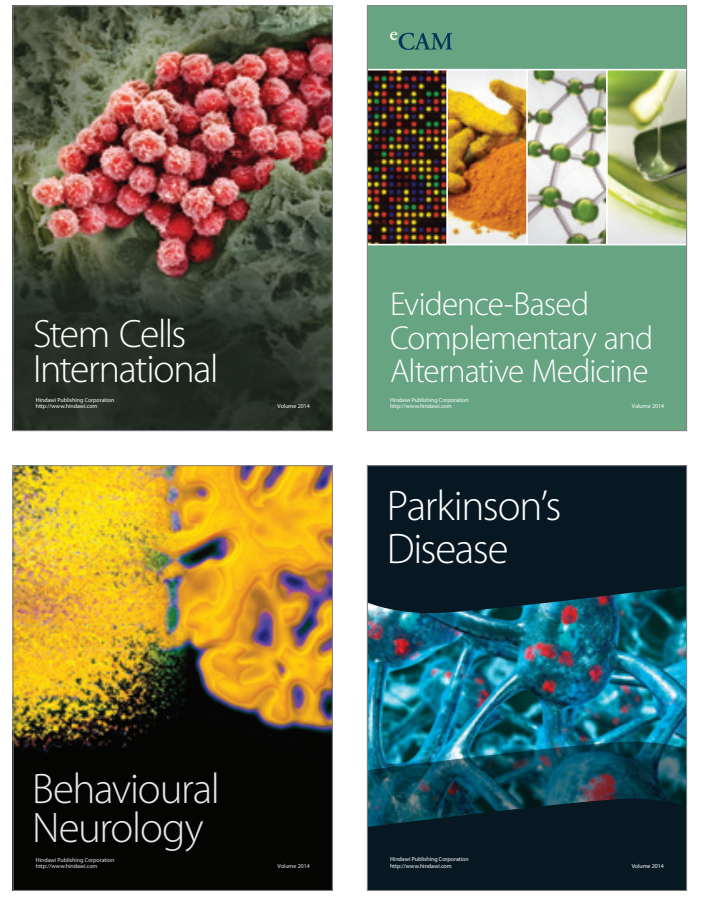
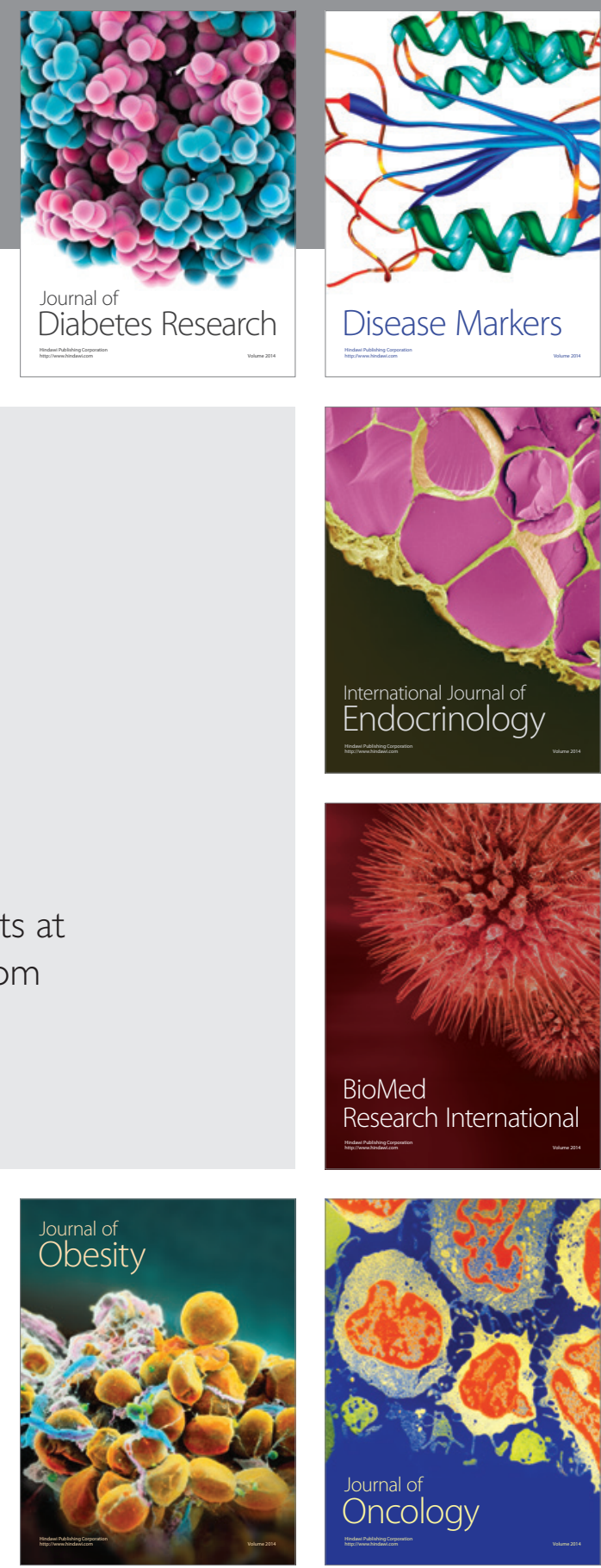

Disease Markers
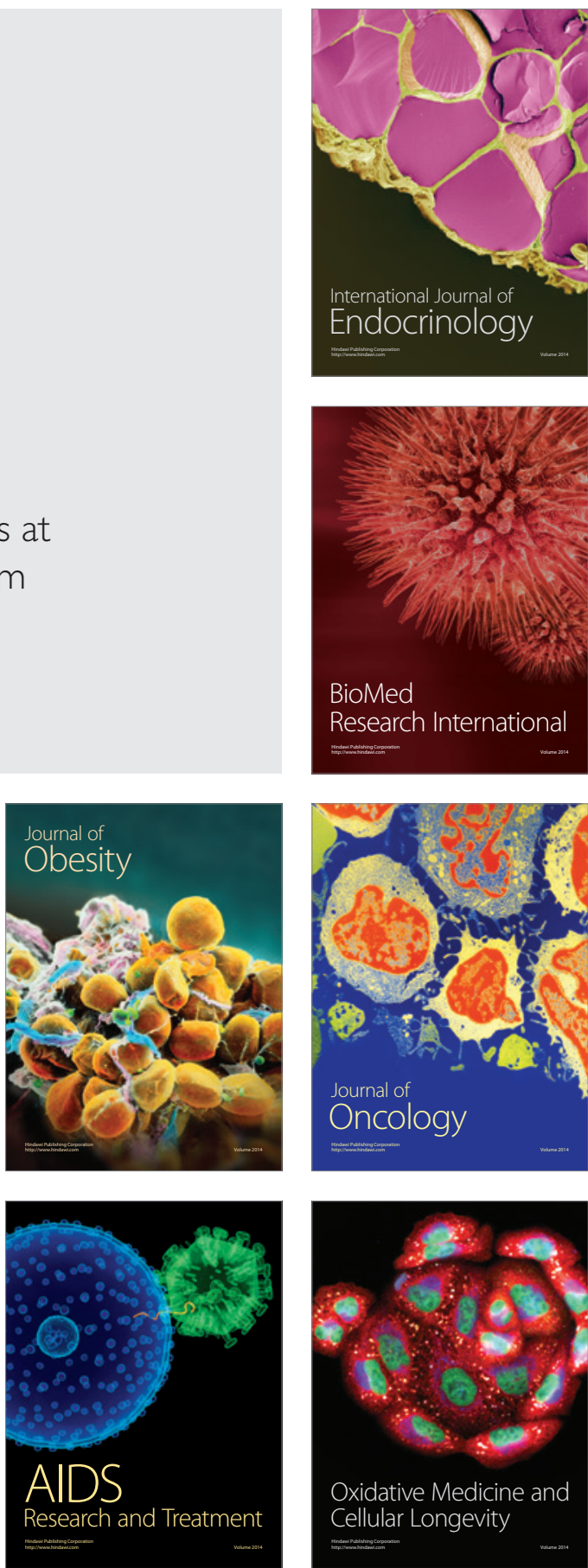